\title{
Reproductive characteristics of an invasive species Carassius gibelio (Bloch, 1782) in Ataturk Dam Lake, Turkey
}

\author{
ARIF PARMAKSIZ1 ${ }^{1}$, SEYIT AHMET OYMAK ${ }^{1}$, NECMETTIN DOGAN², DARLINA \\ MD NAIM $^{3}$ AND ERHAN UNLU ${ }^{4}$ \\ ${ }^{1}$ Department of Biology, Faculty of Science-Literature, Harran University, Sanliurfa, Turkey \\ ${ }^{2}$ Bilgi Anatolian High School, Adlyaman, Turkey \\ ${ }^{3}$ School of Biological Sciences, Universiti Sains Malaysia, 11800 Penang, Malaysia \\ ${ }^{4}$ Department of Biology, Faculty of Science-Literature, Dicle University, Diyarbakır, Turkey \\ e-mail:aprmksz@gmail.com
}

\begin{abstract}
In this study, sex composition, spawning period, fecundity and sexual maturity of the gibel carp, Carassius gibelio (Bloch, 1782), an invasive species in the Atatürk Dam Lake, on Euphrates River,Turkey were studied. C. gibelio specimens were analysed from Ataturk Dam Lake and the percentage of the males and females was $45.55 \%$ and $55.45 \%$ respectively out of the 110 specimens studied, ranging between age groups I -VI. The age at first maturity was three years for both females and males. The diameter of the egg was smallest in September, with a mean of $0.62 \mathrm{~mm}$, while the mean egg diameter in June was greatest, at $1.54 \mathrm{~mm}$. The absolute fecundity ranged from 1054 to 22548 . Reproduction of gibel carp in Atatürk Dam Lake in Turkey was characterised by a young age at first maturity and high spawning capacity that would facilitate population expansion in aquatic environments.
\end{abstract}

Keywords: Carassius gibelio, Fecundity, Gonado-somatic index, Reproduction

\section{Introduction}

Investigations on the reproductive characteristics of fish and understanding the reproductive details of a species is central to the development of successful strategies for sustainable fisheries (Unlu, 1991; Ali and Kadir, 1996; Muchlisin, 2014) and for evaluating the impacts of environmental variability on the dynamics of fish populations (Schlosser, 1990; Tarkan et al., 2009). In addition, information on the reproductive biology of the candidate species is fundamental to the development of aquaculture (Tesch, 1968; Priyadharsini et al., 2013). Consequently, many undescribed species are in potential danger of extinction because of incomplete taxonomy, unrecognised congeneric variation and/or lack of studies on reproductive characteristics (Brophy, 2004).

Carassius gibelio (Bloch, 1872) belonging to the family Cyprinideae has been a subject of a long debate regarding its validity and origin (Yerli et al., 2014). This is a potamodromous species and tolerant to marginal habitats (Kukuradze and Mariash, 1975; Riede, 2004; Docherty et al., 2017). It is also an invasive species and is widely known in Turkey as Israeli carp and thought to be a result of hybridisation or even thought to be a native to far east of Central Europe, introduced to Europe (Ilhan and Sar1, 2013; Yerli et al., 2014). It has wide distribution in Turkey (Ozulug et al., 2004; Innal and Erk'akan, 2006; Gaygusuz et al., 2007, Tarkan et al., 2012; Yerli et al., 2014; Tarkan et al., 2017; Gulsah and Ozulug, 2017). This species is hazardous for native fish communities in Turkey (Gozlan et al., 2010; Aydin et al., 2011; Tarkan et al., 2017) and has become one of the dominant species which may change the flow of nutrients in the entire ecosystem (Paulovits et al., 1998; Yilmaz et al., 2004).

Ataturk Dam was commissioned in 1990 for irrigation and hydroelectric purposes. It is one of the largest man-made dams in Turkey, which occupies an area of approximately $817 \mathrm{~km}^{2}$, making the lake the biggest artificial reservoir in Turkey (Oymak et al., 2011). For its large size and ecological properties, it has very high potential for fisheries. There are 28 species and subspecies belonging to 8 families in Ataturk Dam Lake (Bozkurt, 1994; Oymak et al., 2001). However, the number of native species in the lake decreased after the introduction of C. gibelio through restocking of carp fry (Leonardos et al., 2008; Emiroglu et al., 2012).

Studies of C. gibelio in Turkey, are limited and information on its reproductive performance is scarce (Balik et al., 2004; Tarkan et al., 2009; Emiroglu et al., 2011; Emiroglu et al., 2012; Tarkan et al., 2012; Kirankaya and Ekmekci, 2013). Likewise, there is no scientific study 
on reproduction of $C$. gibelio population in the Ataturk Dam Lake, till date.

Gibel carp is becoming the most dominant species in many aquatic environments with high adaptation to different ecological conditions (Lusk et al., 2010). For this reason, the reproductive success of populations in different environments need to be investigated and monitored. The purpose of this study was to describe the reproductive characteristics including sex ratio, age at sexual first maturity, spawning time, gonado-somatic index, ova diameter and fecundity of $C$. gibelio from the Atatürk Dam Lake, the biggest reservoir in Turkey and to make comparisons among the different localities within the lake.

\section{Materials and methods}

Samples of $C$. gibelio were collected from January to November 2009 at monthly intervals from Ataturk Dam Lake near Kahta and Samsat Town of Adiyaman in Turkey (Fig. 1).

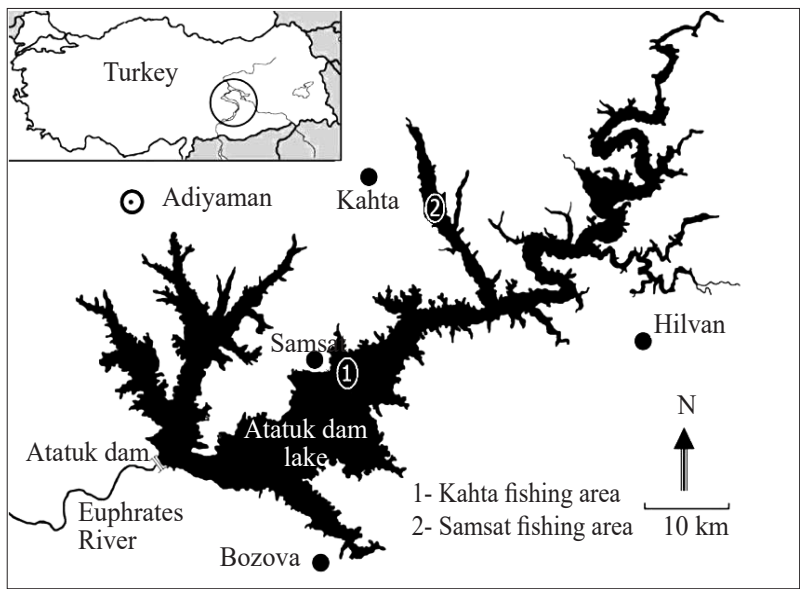

Fig. 1. Map of the study area (Oymak et al., 2011)

Overall, 110 specimens (61 females and 49 males) of C. gibelio were collected using gillnets of various mesh sizes $(18 \times 18 \mathrm{~mm}, 24 \times 24 \mathrm{~mm}$ and 30x30 mm). The fish were brought to the laboratory in an icebox the same day. Specimens were tagged after biometric data on sex; fork length (FL) and weight (W) measurements were recorded (Table 1). FL was measured to nearest $1 \mathrm{~mm}$ and weight to nearest $1 \mathrm{~g}$. The age of the specimens were identified by checking the scales according to the criteria described by Polat (1987). For this purpose, approximately 10 scales were taken from the mid-body behind the pectoral fins of each individual sampled. The scales were mounted between two glass microscope slides and they were assessed by Kindermann Microfiche Reader. Sex was determined by examination of the gonads either visually for the larger individual samples or with the aid of a binocular stereo microscope for the smaller samples.

The gonads were separated and weighed to the nearest $0.01 \mathrm{~g}$. The monthly gonado-somatic index (GSI) was calculated according to the equation as established by Wootton (1990): GSI = Gonad weight (g) / Body weight (g) X 100. Sex ratio was estimated for all fish caught and comparisons of sex ratio based on the expected 1:1 ratio were made by Chi-square test at confidence level of $95 \%$. Maturity of samples was detected by visual inspection of the gonads in the samples caught in months close to the reproductive period.

The age at which $50 \%$ of fish were mature was considered as the age at first maturity for both sexes (Oymak et al., 2011). The average length of fish at this age was evaluated to be the length at first maturity. To determine the fecundity of $C$. gibelio, the number of eggs produced by individual fish was calculated by the gravimetric method from ovaries which had been preserved in 4\% formalin solution (Laevastu, 1965) so as to enumerate the total number of eggs in the particular ovary. From each ovary, 20 ova were chosen at random and the mean diameter for each egg was manually measured to the nearest $\mathrm{mm}$. The relative fecundity (Fr) was expressed by dividing the absolute fecundity by the fish body weight (Bagenal, 1978). The relationship between fecundity (F) and fork length (FL, mm), body weight $(\mathrm{W}, \mathrm{g})$ and gonad weight $(\mathrm{GW}, \mathrm{g})$ of fish were determined by using the power regression equation $\mathrm{F}=\mathrm{aX}$, where $\mathrm{F}=$ Fecundity, $\mathrm{X}=$ Standard length of fish (mm) or weight of fish $(\mathrm{g}), \mathrm{a}=$ Regression constant and $b=$ Regression coefficient. The relationship was log transformed into a straight line, as $\log \mathrm{Y}=\mathrm{a}+\mathrm{b} \log \mathrm{X}$ (Wootton, 1990).

\section{Results and discussion}

\section{Length and weight of monthly samples}

The number, fork length and body weight of the 110 specimens of $C$. gibelio collected monthly from Atatürk Dam Lake during the study are given in Table 1. The length and body weight were in the range $80-252 \mathrm{~mm}$ and $9-328 \mathrm{~g}$ respectively.

\section{Sex ratio, age and size at first maturity}

From the total 110 specimens collected, 61 were females and 49 males, with an overall sex ratio of 1: 0.80 (female to male). The difference between the number of females and males was not significant $\left(\chi^{2}=1.309, p>0.05\right)$ from the expected $1: 1$ ratio.

The results showed that six age groups for both females and males were represented in the current study 
Table 1. Number (n), length and weight (mean $\pm \mathrm{SD})$ of $C$. gibelio sampled monthly during the study period between January and November 2009 from the Atatürk Dam Lake

\begin{tabular}{|c|c|c|c|c|c|c|}
\hline \multirow[b]{3}{*}{ Month } & \multicolumn{3}{|c|}{ Female } & \multicolumn{3}{|c|}{ Male } \\
\hline & & Fork length $(\mathrm{mm})$ & Weight (g) & & Fork 1 ength $(\mathrm{mm})$ & Weight (g) \\
\hline & $\mathrm{n}$ & Mean \pm SD & Mean \pm SD & $\mathrm{n}$ & Mean \pm SD & Mean \pm SD \\
\hline January & 5 & $190.0 \pm 6.12$ & $161.8 \pm 17.08$ & 3 & $140.8 \pm 92.41$ & $137.3 \pm 24.58$ \\
\hline February & 4 & $189.0 \pm 9.87$ & $150.5 \pm 32.62$ & 2 & $111.0 \pm 94.87$ & $80.0 \pm 14.14$ \\
\hline March & 8 & $174.4 \pm 21.95$ & $118.1 \pm 43.81$ & 2 & $105.7 \pm 89.81$ & $75.0 \pm 9.90$ \\
\hline April & 6 & $97.7 \pm 14.39$ & $18.7 \pm 8.07$ & 7 & $103.8 \pm 50.93$ & $33.1 \pm 31.11$ \\
\hline May & 5 & $151.8 \pm 52.10$ & $87.0 \pm 85.25$ & 2 & $73.3 \pm 65.25$ & $20.0 \pm 11.31$ \\
\hline June & 6 & $197.5 \pm 8.38$ & $136.0 \pm 19.56$ & 4 & $140.2 \pm 79.10$ & $97.8 \pm 52.45$ \\
\hline July & 9 & $189.4 \pm 17.78$ & $127.8 \pm 31.52$ & 11 & $156.3 \pm 49.51$ & $85.8 \pm 35.39$ \\
\hline August & 2 & $187.5 \pm 3.54$ & $114.5 \pm 0.71$ & 4 & $168.8 \pm 92.13$ & $172.0 \pm 7.87$ \\
\hline September & 5 & $194.4 \pm 16.79$ & $143.2 \pm 45.05$ & 4 & $147.4 \pm 85.44$ & $122.8 \pm 57.35$ \\
\hline October & 6 & $192.2 \pm 31.81$ & $164.5 \pm 84.61$ & 6 & $152.3 \pm 69.36$ & $150.8 \pm 76.91$ \\
\hline November & 5 & $190.8 \pm 30.31$ & $166.0 \pm 84.37$ & 4 & $165.2 \pm 91.94$ & $184.0 \pm 72.54$ \\
\hline
\end{tabular}

(Table 2). The highest frequency of fish caught occurred at 5 years age $(63.9 \%$ for females and $42.9 \%$ for males). t-test analysis revealed that the age differences were not significant between females and males $(t=0.6182$, $\mathrm{df}=5, \mathrm{p}>0.05)$.

Table 2 shows the summary of age at sexual maturity based on the results obtained from the gonad examination of $C$. gibelio collected in this study. It was observed that all of the females with $95 \mathrm{~mm}$ and males with $90 \mathrm{~mm}$ fork length and those older than three years were mature individuals.

\section{Spawning season}

In order to determine the spawning season of C. gibelio, the mean gonado-somatic index and mean egg diameter were calculated monthly (Fig. 2 and 3). The results revealed that the peak GSI values of 16.77 and 5.06 respectively for females and males were observed in the month of May. The lowest mean value for females was found in November (GSI $=2.72$ ) and for males in August $(\mathrm{GSI}=1.06)$. The mean GSI values were found to diminish from November until the new spawning season.
The mean egg diameter, measured monthly from January to November 2009, was highest in May with a mean of 1.54 and lowest in September with a mean of $0.62 \mathrm{~mm}$ when the ovaries contain only oocytes which would develop the following year. As shown in Fig. 2 and 3 , there is a strong relationship between GSI values and egg diameter with month. This trend of GSI values and seasonal development in ova size showed that the spawning took place in May and continued until late June in the population.

\section{Fecundity}

Absolute fecundity was estimated in adult females during the study. Individual values of the absolute fecundity varied in a wide range from 1054 to 22548 with a mean of $9202 \pm 5727(\mathrm{n}=58)$ in C. gibelio. The relative fecundity was 5.67 to 379.38 eggs with a mean of $96.89( \pm 91.31)$ per gram of body weight.

Absolute fecundity was significantly related to female body length and gonad weight, with the regression coefficient values of 0.680 (Table 3). Other relationships between fecundity with fish length and fish weight, although positive, were not significant $(\mathrm{p}>0.05)$.

Table 2. Age group and the maturity percentage of females and males of $C$. gibelio from the Ataturk Dam Lake

\begin{tabular}{|c|c|c|c|c|c|c|c|c|c|c|}
\hline \multirow[b]{2}{*}{ Age group } & \multicolumn{5}{|c|}{ Female } & \multicolumn{5}{|c|}{ Male } \\
\hline & $\mathrm{n}$ & IM & IM\% & M & M \% & $\mathrm{n}$ & $\mathrm{IM}$ & $\mathrm{IM} \%$ & $\mathrm{M}$ & M \% \\
\hline I & - & - & - & - & & - & - & & - & \\
\hline II & 2 & 2 & 100.0 & - & 0.0 & 2 & 2 & 100.0 & 1 & 25.0 \\
\hline III & 5 & 1 & 20.0 & 4 & 80.0 & 6 & 2 & 33.3 & 4 & 67.7 \\
\hline IV & 10 & 0 & 0.0 & 10 & 100.0 & 13 & 0 & 0.0 & 13 & 100.0 \\
\hline $\mathrm{V}$ & 39 & 0 & 0.0 & 39 & 100.0 & 21 & 0 & 0.0 & 21 & 100.0 \\
\hline VI & 5 & 0 & 0.0 & 5 & 100.0 & 7 & 0 & 0.0 & 7 & 100.0 \\
\hline
\end{tabular}

$\mathrm{n}=$ Number of fish; $\mathrm{IM}=$ Immature; $\mathrm{M}=$ Mature 


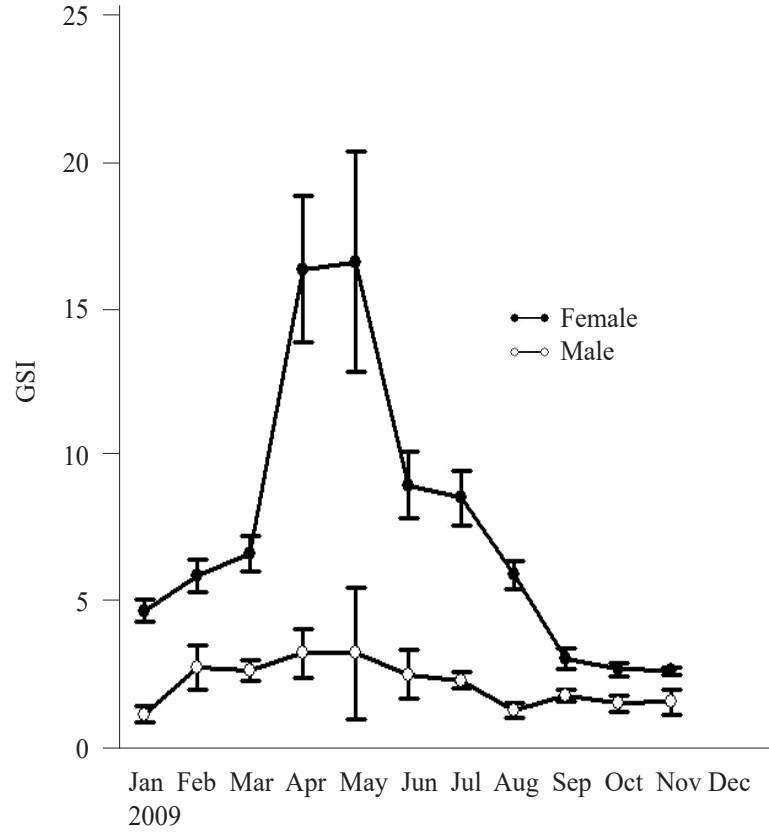

Fig. 2. Gonado-somatic index (GSI) of C. gibelio from the Ataturk Dam Lake

Table 3. Correlation coefficients and regression equation for relationships between absolute fecundity (F) and body length (FL), body weight (W) and weight of gonad (GW) of C. gibelio from the Ataturk Dam Lake

\begin{tabular}{lllllll}
\hline Relationship & $\mathrm{n}$ & Power regression & $\mathrm{r}$ & $\mathrm{r}^{2}$ & $\mathrm{~F}$ & $\mathrm{p}$ \\
\hline F-FL & 58 & $\mathrm{~F}=1108.919 \mathrm{FL}^{0.3614}$ & 0.091 & 0.008 & 0,4679 & 0,4967 \\
F-W & 58 & $\mathrm{~F}=6289.267 \mathrm{~W}^{0.0292}$ & 0.024 & 0.001 & 0.0311 & 0.8606 \\
F-GW & 58 & $\mathrm{~F}=1139.725 \mathrm{GW}^{0.9542}$ & 0.680 & 0.462 & 48.0524 & 0.0000 \\
\hline
\end{tabular}

Fecundity of $C$. gibelio revealed that it was more related to gonad weight than to body length and body weight.

According to Tarkan et al. (2012) non-native gibel carp populations inhabiting different types of aquatic ecosystems in Turkey could be differentiated by their life history traits and growth patterns. Considered a typical invasive alien species, $C$. gibelio heavily depressed the occurrence and numbers of indigenous $C$. carassius populations and native cyprinid fish (Kukuradze and Mariash, 1975; Lusk et al., 2010).

In this study, 110 (61 females and 49 males) specimens of $C$. gibelio were caught from Ataturk Dam Lake, ranging from age group I to VI, in which, age group $\mathrm{V}$ represented the highest number of specimens obtained $($ females $=39$ and males $=21)$ (Table 1$)$. The results corroborate the studies conducted by Balik et al. (2004) in Turkey in which the specimens were represented by age group I to VI. More age groups were recorded in the study conducted by Emiroglu et al. (2012) in the Lake Uluabat (419 females and 153 males) where the age group ranged

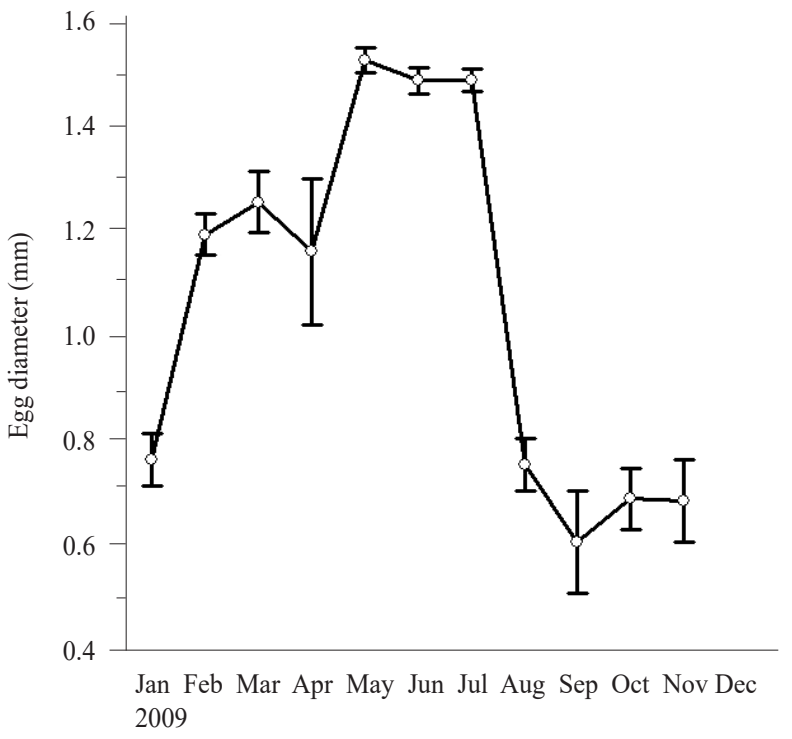

Fig. 3. Egg diameter of C. gibelio from the Atatürk Dam Lake

from I to XII. Likewise, Tarkan et al. (2012) reported age group from I to XI for a total of 1380 (1060 females and 320 males) individuals collected from 16 water bodies in Turkey. These variations could be attributed to either environmental changes, the length of time since introduction Tarkan et al. (2010), variations in fishing techniques during sampling activity, feeding habits of fish and the ecological characteristics of the lakes.

The age structure of $C$. gibelio at the sampling location in Ataturk Dam Lake indicates that most specimens leave the location and probably migrate into other locations not included in this current study during their first year of life. Another possible factor for the absence of age group I in our data may be due to water temperature which may directly or indirectly influence the food availability at the sampling locations.

In this study, most individuals spawned during May to June, while in Lake Egirdir, the most intensive period for reproduction was from April to July (Balik et al., 2004) and in Lake Uluabat, from March to early May (Emiroglu et al., 2012). In 16 water bodies in Turkey, the species spawned mainly from early April to late June (Tarkan et al., 2012) and in Ikizcetepeler Dam Lake, their spawning period was mainly from early April and July (Erdogan et al., 2014). The difference in some localities are thought to be due to climatic conditions, especially due to the higher temperature of water. In this study, the highest mean ova diameter was recorded in May $(1.54 \mathrm{~mm})$ and lowest in September with a mean of $0.62 \mathrm{~mm}$. In Lake Uluabat, mean egg diameter was highest in March $(0.98 \mathrm{~mm})$ while it was lowest in July (0.69 mm) (Emiroglu et al., 2012). Tarkan et al. (2012) 
recorded highest mean egg diameter of $1.34 \mathrm{~mm}$ in May from 16 water bodies in Turkey. Egg size reported in our study is the highest which may be attributed to feeding. In this study, fecundity was estimated in females captured just prior to spawning and the number of eggs ranged from 1054 to 22548. Fecundity ranged from 42000 to 141000 in Lake Egirdir (Balik et al., 2004) and in Lake Uluabat (Emiroglu et al., 2012), it ranged from 1822 to 80,000 in 16 water bodies in Turkey (Tarkan et al., 2012). These differences in the number of eggs are influenced by age, size and nutrition of fish (Wootton, 1990) and various physico-chemical factors (Schlosser, 1990; Schulte, 2014). Absolute fecundity was found to be linear with gonad weight which indicates that the number of eggs increases with ovary weight. Similar findings were reported by Emiroglu et al. (2012) for C. gibelio and by Ortega-Salas and Reyes-Bustamante (2006) for C. auratus.

Data obtained from this study could be used as baseline data for carrying out future investigations and may provide valuable information needed for monitoring and management of invasive species in aquatic environments.

\section{Acknowledgements}

This study was funded by Harran University Research Fund (Project No: 1151). The authors report no conflicts of interest.

\section{References}

Ali, A. B. and Kadir, B. K. A. 1996. The reproductive biology of the cyprinid, Thynnichthys thynnoides (Bleeker), in the Chenderoh Reservoir - a small tropical reservoir in Malaysia. Hydrobiologia, 318: 139-151.

Aydin, H., Gaygusuz, O., Tarkan, A. S., Top, N., Emiroglu, O. and Gursoy Gaygusuz, C. 2011. Invasion of freshwater bodies in Marmara Region (NW-Turkey) by non-native gibel carp, Carassius gibelio (Bloch, 1782). Turk. J. Zool., 35: 829-836.

Bagenal, T. B. 1978. Aspects of fish fecundity. In: Bagenal, T. B. (Ed.), Methods for assessment of fish production in freshwaters, Blackwell Science, Oxford, p. 75-101.

Balik, I., Ozkok, R., Cubuk, H. and Uysal, R. 2004. Investigation of some biological characteristics of the silver crucian carp, Carassius gibelio (Bloch, 1782) population in Lake Egirdir. Turk. J. Zool., 28: 19-28.

Bozkurt, R. 1994. Systematics of fishes in Atatürk Dam Lake and in streams plunging in to the Dam Lake. M. Sc. Thesis. Graduate School of Natural and Applied Sciences, Harran University, Turkey, $71 \mathrm{pp}$.

Brophy, T. R. 2004. Geographic variation and systematic in the south-east Asian turtles of the genus Malayemys (Testudines: Bataguridae). Hamadryad, 29: 63-79.
Docherty, C., Ruppert, J., Rudolfsen, T., Hamann, A. and Poesch, M. S. 2017. Assessing the spread and potential impact of Prussian Carp Carassius gibelio (Bloch, 1782) to freshwater fishes in western North America. Bio-Invasions Rec., 6: 291-296.

Emiroglu, O., Bayramoglu, G., Ozturk, D. and Yaylaci, O. K. 2011. Determinaton of the gynogenetic reproduction character of Carassius gibelio in Uluabat Lake. Asian J. Anim. Vet. Adv., 6: 648-653.

Emiroglu, O., Tarkan, S., Top, N., Baskurt, S. and Sulun, S. 2012. Growth and life history traits of a highly exploited population of non-native Gibel Carp, Carassius gibelio from a large eutrophic lake (Lake Uluabat, NW Turkey): Is reproduction the key factor for establishment success? Turk. J. Fish. Aquat. Sci., 12: 925-936.

Erdogan, Z., Torcu Koc, H., Gungor, S. and Ulunehir, G. 2014. Age, growth and reproductive properties of an invasive species Carassius gibelio (Bloch, 1782) (Cyprinidae) in the Ikizcetepeler Dam Lake (Balikesir), Turkey. Periodicum Biologorum, 116: 285-291.

Gaygusuz, O., Tarkan, A. S. and Gaygusuz, C. 2007. Changes in the fish community of the Omerli Reservoir (Turkey) following the introduction of non-native gibel carp Carassius gibelio (Bloch, 1782) and other human impacts. Aquat. Invasions, 2: 117-120.

Gozlan, R. E., Britton, J. R., Cowx, I. and Copp, G. H. 2010 Current knowledge on non-native freshwater fish introductions. J. Fish Biol., 76: 751-786.

Gulsah, S. A. C. and Ozulug, M. 2017. New data on distribution of three invasive freshwater fish species in Istanbul (Turkey). Acta Biologica Turcica, 30: 11-15.

Innal, D. and Erk'akan, F. 2006. Effects of exotic and translocated fish species in the inland waters of Turkey. Rev. Fish Biol. Fish., 16: 39-50.

Ilhan, A. and Sarı, H. M. 2013. Fish fauna and fisheries activities in Lake Marmara. Ege J. Fish. Aquat. Sci., 30: 187-191.

Kirankaya, S. and Ekmekci, F. 2013. Life-history traits of the invasive population of Prussian carp, Carassius gibelio (Actinopterygi: Cypriniformes: Cyprinidae), from Gelingullu Reservoir, Yozgat, Turkey. Acta Ichthyol. et Piscat., 43: 31-40.

Kukuradze, A. M. and Mariyash, L. F. 1975. Information on the ecology of wild goldfish (Carassius auritus gibelio) in the lower reaches of the Danube. J. Ichthyol., 15: 409-415.

Laevastu, T. 1965. Manual of methods in fisheries biology. FAO Manuals in Fisheries Science, 49: 37-45.

Leonardos, I. D., Tsikliras, A. C., Eleftheriou, V., Cladas, Y., Kagalou, I., Chortatou, R. and Papigioti, O. 2008. Life history characteristics of an invasive cyprinid fish (Carassius gibelio) in Chimaditis Lake (northern Greece). J. Appl. Ichthyol., 24: 213-217. 
Lusk, M. R., Luskova, V. and Hanel, L. 2010. Alien fish species in the Czech Republic and their impact on the native fish fauna. Folia Zoologica, 59: 57-72.

Muchlisin, Z. A. 2014. A general overview on some aspects of fish reproduction. Aceh Int. J. Sci. Technol., 3(1): 43-52.

Ortega-Salas, A. A. and Reyes-Bustamante, H. 2006. Initial sexual maturity and fecundity of the goldfish Carassius auratus (Perciformes: Cyprynidae) under semi-controlled conditions. Rev. De Biol. Trop., 54(4): 1113-1116.

Oymak, S. A., Solak, K. and Unlu, E. 2001. Some biological characteristics of Silurus triostegus Heckel, 1843 from Ataturk Dam Lake (Turkey). Turk. J. Zool., 25: 139-148.

Oymak, S. A., Unlu, E., Parmaksiz, A. and Dogan, N. 2011. A study on the age, growth and reproduction of Aspius vorax (Heckel, 1843) (Cyprinidae) in Atatürk Dam Lake (Euphrates River), Turkey. Turk. J. Fish. Aquat. Sci., 11: 217-225.

Ozulug, M., Meric, N. and Freyhof, J. 2004. The distribution of Carassius gibelio (Bloch, 1782) (Teleostei: Cyprinidae) in Thrace (Turkey). Zool. Middle East, 31: 63-66.

Paulovits, G., Tatrai, I., Matyas, K., Korponai, J. and Kovats, N. 1998. Role of Prussian carp (Carassius auratus gibelio Bloch) in the nutrient cycle of the Kis-Balaton Reservoir. Int. Rev. Hydrobiol., 83: 467-470.

Polat, N., 1987. Age determination of Capoeta trutta (Heckel, 1843) in Keban Dam Lake. Turk. J. Zool., 11: 155-160.

Priyadharsini, S., Manoharan, J., Varadharajan, D. and Subramaniyan, A. 2013. Reproductive biology and histological study of red lionfish Pterois volitans from Cuddalore, south-east coast of India. J. Aquac. Res. Dev., 4: $1-9$

Riede, K. 2004. Global register of migratory species - from global to regional scales. Final report of the $R \& D$ Project 80805 081. Federal Agency for Nature Conservation, Bonn, Germany, 329 pp.

Schlosser, I. J. 1990. Environmental variation, life history attributes and community structure in stream fishes: implications for environmental management and assessment. Environ. Manag., 14: 621-628.

Schulte, P. M. 2014. What is environmental stress? Insights from fish living in a variable environment. J. Exp. Biol., 217: $23-34$
Tarkan, A. S., Copp, G. H., Zieba, G., Godard, M. J. and Cucherousset, J. 2009. Growth and reproduction of threatened native crucian carp Carassius carassius in small ponds of Epping Forest, south-east England. Aquat. Conserv. Mar. Freshw. Ecosyst., 19: 797-805.

Tarkan, A. S., Cucherousset, J., Zieba, G., Godard, M. J. and Copp, G. H. 2010. Growth and reproduction of introduced goldfish Carassius auratus in small ponds of south-east England with and without native crucian carp Carassius carassius. J. Appl. Ichthyol., 26: 102-108.

Tarkan, A. S., Copp, G. H., Top, N., Ozdemir, N., Onsoy, B., Bilge, G., Filiz, H., Yapici, S., Ekmekci, G., Kirankaya, S., Emiroglu, O., Gaygusuz, O., Gursoy Gaygusuz, C., Oymak, A., Ozcan, G. and Sac, G. 2012. Are introduced gibel carp Carassius gibelio in Turkey more invasive in artificial than in natural waters? Fish. Manag. Ecol., 19: $178-187$.

Tarkan, A. S., Sarı, H. M., Ilhan, A., Kurtul, I. and Vilizzi, L. 2017. Risk screening of non-native and translocated freshwater fish species in a Mediterranean-type shallow lake: Lake Marmara (West Anatolia). Zool. Middle East, 63(1): 48-57.

Tesch, F. W. 1968. Age and growth in methods for assessment of fish production. In: Ricer, W. E. (Ed.), Methods for assessment of fish production in freshwater, IBP Handbook, Blackwell Science Publication, p. 93-123.

Unlu, E. 1991. A study on the biological characteristics of Capoeta trutta (Heckel, 1843) living in the Tigris River, Turkey. Turk. J. Zool., 15: 22-38.

Wootton, R. J. 1990. Ecology of teleost fishes. Chapman and Hall, London, 404 pp.

Yerli, S. V., Mangit, F., Emiroglu, O., Yegen, V., Uysal, R., Unlu, E. and Zengin, M. 2014. Distribution of invasive Carassius gibelio (Bloch, 1782) (Teleostei: Cyprinidae) in Turkey. Turk. J. Fish. Aquat. Sci., 14: 581-590.

Yilmaz, M., Bostanci, D., Yilmaz, S. and Polat, N. 2004. Egirdir Golu (Isparta)'nde yaşayan havuzbalıg1 (Carassius gibelio BLOCH, 1782)'nın beslenme rejimi. Turk. J. Aquat. Life, 2: $230-239$. 